\title{
The Synthesis of Enzymes Concerned in Bacterio- chlorophyll Formation in Growing Cultures of Rhodopseudomonas spheroides
}

\author{
BY JUNE LASCELLES \\ Microbiology Unit, Department of Biochemistry, University of Oxford
}

(Received 10 May 1960)

\section{SUMMARY}

The enzymes $\delta$-aminolaevulic acid synthetase and $\delta$-aminolaevulic acid dehydrase are concerned in the early stages of tetrapyrrole formation; factors controlling their synthesis have been studied in cultures of Rhodopseudomonas spheroides growing exponentially. In organisms growing in the dark under high degrees of aeration the differential rate of synthesis (increase in enzyme/increase in culture density) of both enzymes is about one-third of that in cultures growing anaerobically in the light. Organisms growing in the dark under low degrees of aeration form the enzymes at rates comparable to those in photosynthetic cultures. Under anaerobic conditions the differential rate of synthesis of both enzymes is decreased by increasing the light intensity. Enzyme synthesis in the light is repressed by oxygen, the effect being overcome on restoration of anaerobic conditions. Formation of bacteriochlorophyll under these various conditions is affected in the same way as enzyme synthesis. Addition of $\delta$-aminolaevulic acid or haemin to growing cultures stopped the synthesis of the synthetase and the dehydrase; magnesium protoporphyrin had no such effect. The activity of the synthetase, but not of the dehydrase, was decreased in organisms growing with suboptimal concentrations of biotin. A component of the electron transport chain as well as the intracellular concentration of biosynthetic intermediates may contribute, by mechanisms as yet unknown, to the regulation of synthesis of enzymes involved in bacteriochlorophyll formation.

\section{INTRODUCTION}

Rhodopseudomonas spheroides and other members of the Athiorhodaceae are able to grow in the light or in the dark and there is a close connexion between the growth conditions and the formation of the photosynthetic pigments, bacteriochlorophyll and carotenoids. These are synthesized by organisms growing anaerobically in the light but only traces are found in cultures grown in the dark under high aeration (van Niel, 1944; Cohen-Bazire, Sistrom \& Stanier, 1957). R. spheroides can form pigments in the dark but only when the oxygen tension is decreased (Cohen-Bazire et al. 1957; Lascelles, 1959). The mechanism of adjustment of the pigment content to suit the environment is undoubtedly complex but the degrees of activity of enzymes concerned in pigment synthesis may contribute. This possibility has been examined in $R$. spheroides in the case of bacteriochlorophyll which is probably formed by a pathway which includes the intermediates shown in Fig. 1 (Lascelles, 
$1956 a$; Cooper, 1956; Kikuchi, Kumar, Talmage \& Shemin, 1958; Gibson, 1958; Heath \& Hoare, 1959; Hoare \& Heath, 1959). It was found previously that the activities of $\delta$-aminolaevulic acid (ALA) synthetase and ALA dehydrase were correlated with the ability to form bacteriochlorophyll, both enzymes being about five times more active in organisms grown photosynthetically than in those grown in the dark under high aeration (Lascelles, 1959). In the present work a study has been made of the influence of the environment, including the gas phase and constituents of the medium, on the rates of synthesis of these enzymes in exponentially growing cultures.

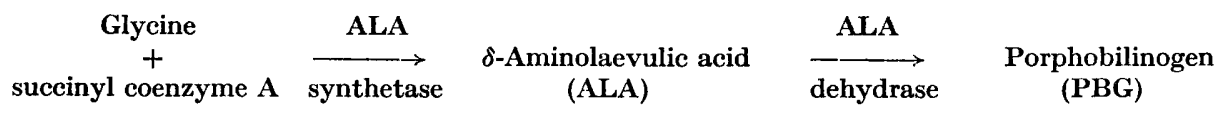

$\longrightarrow$ Uroporphyrinogen III $\longrightarrow$ Coproporphyrinogen III

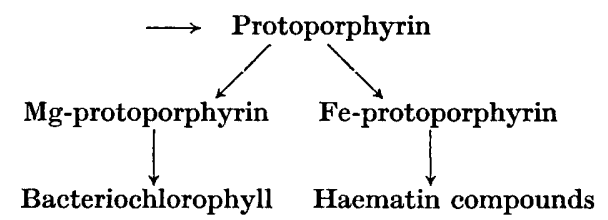

Fig. 1. Pathway of synthesis of tetrapyrrole derivatives in Rhodopseudomonas spheroides.

\section{METHODS}

Organism. The strain of Rhodopseudomonas spheroides (NCIB no. 8253) and the maintenance of stock cultures were described previously (Lascelles, $1956 a$ ).

Medium. All experiments were made with cultures growing in the chemically defined medium containing malate and glutamate and supplemented with iron citrate (0.01 mu) which has been described before (Lascelles, 1959).

Inoculation of cultures. To obtain exponentially growing cultures organisms were first grown in the above medium either anaerobically in the light or aerobically in the dark as described by Lascelles (1959). They were harvested by centrifugation at the end of the exponential phase of growth (about $16 \mathrm{hr}$.), when the density had reached 0.9-1.0 mg. dry wt. organism $/ \mathrm{ml}$. The centrifuged organisms were resuspended in fresh medium to a density equivalent to $c . \mathbf{0 . 2} \mathbf{m g}$. dry wt./ml. and then incubated under the appropriate conditions.

Conditions of incubation. Most experiments were made with cultures growing anaerobically in the light in Drechsel bottles (capacity $275 \mathrm{ml}$.); anaerobiosis, as well as mixing of the cultures, was maintained by continuously passing a gentle stream of $5 \%(\mathrm{v} / \mathrm{v}) \mathrm{CO}_{2}$ in $\mathrm{N}_{2}$. The culture bottles were incubated in a glass-sided water bath at $34^{\circ}$; each vessel was illuminated by a $100 \mathrm{~W}$. tungsten lamp mounted in a reflector clamped outside the bath and $10 \mathrm{~cm}$. from the centre of the culture. These conditions are referred to as 'standard'. In some experiments a high light intensity was used, Philips 'Photolita' no. 1 (275 W.) photoflood lamps being substituted for the $100 \mathrm{~W}$. lamps. Other deviations from the standard conditions are noted in the text.

For aerobic incubation in the dark, cultures were grown in $\perp$-shaped tubes similar to those described by Monod, Cohen-Bazire \& Cohn (1951); the horizontal limb containing the culture was of $3 \cdot 3 \mathrm{~cm}$. internal diameter and $19 \mathrm{~cm}$. long. These 
were clamped to a rocking device (see van Heyningen \& Gladstone, 1953) and shaken at 36 oscillations $/ \mathrm{min}$. in a water bath at $34^{\circ}$. For growth under a high degree of aeration each $\perp$-tube contained $50 \mathrm{ml}$. culture; conditions of low aeration were achieved by using $100 \mathrm{ml}$. culture/vessel, which almost filled the horizontal limb.

Estimation of growth, bacteriochlorophyll and protein. Growth was determined by measuring the extinction of cultures at $680 \mathrm{~m} \mu$ with a Unicam spectrophotometer (SP-600); the dry wt. organism/ml. was calculated from calibration curves obtained with organisms grown either anaerobically in the light or aerobically in the dark. The protein content of the organisms was $50 \%$ of the dry wt. by the method of Stickland (1951).

Bacteriochlorophyll in the organisms and protein in the cell-free extracts were estimated as described previously (Lascelles, 1959).

Preparation of culture samples for assay. At intervals samples were removed from the growing cultures for estimation of dry wt. of organisms, bacteriochlorophyll and enzymic activity. The volume removed depended on the culture density, varying from 25 to $100 \mathrm{ml}$., of which $6 \mathrm{ml}$. were used for determination of the dry wt. and bacteriochlorophyll. The rest of the sample, containing 15-20 mg. dry wt. organism, was centrifuged, the organisms washed in $0.02 \mathrm{M}-2$-amino-2-hydroxymethylpropane-1:3-diol (tris) buffer ( $\mathrm{pH} \mathrm{7 \cdot 4}$ ) and finally suspended in 4-5 ml. of 0.04 $\mathrm{M}$ tris buffer $(\mathrm{pH} 7 \cdot 4)$. When necessary these suspensions were stored at $-20^{\circ}$ before preparation of the cell-free extracts for estimation of ezyme activity.

Preparation of cell-free extracts. The suspensions were disrupted by ultrasonic vibration for $2 \mathrm{~min}$. at $600 \mathrm{~W}$. and $25 \mathrm{kc}$. $/ \mathrm{sec}$. with a Mullard ultrasonic generator type E 7590 B (Mullard Ltd., London, W.C. 1); the transducer assembly was cooled by immersion in a rapidly flowing stream of tap water. Whole organisms and debris were removed by centrifugation at $25,000 \mathrm{~g}$ for $10 \mathrm{~min}$. at $0^{\circ}$. The supernatant fluid containing between 1 and $3 \mathrm{mg}$. protein/ml. was used in the assays for enzymic activity without further treatment.

Assays of enzymic activity. The enzyme system responsible for the condensation of glycine and succinyl coenzyme A to give ALA (referred to as ALA synthetase) was studied in partially purified preparations from Rhodopseudomonas spheroides by Kikuchi et al. (1958), Kikuchi, Kumar \& Shemin (1959) and by Gibson (1958). It was assayed by a method modified slightly from that used previously (Lascelles, 1959). The reaction mixture contained: extract of organisms (0.6-1.5 mg. protein); tris buffer ( $\mathrm{pH} \mathrm{7 \cdot 4}), 50 \mu$ mole; $\mathrm{MgCl}_{2}, 12 \cdot 5 \mu$ mole; glutathione, $1 \mu$ mole; coenzyme A (CoA), $0.05 \mu$ mole; pyridoxal phosphate, $0 \cdot 1 \mu$ mole; adenosine triphosphate (ATP) $8 \mu$ mole; glycine and sodium succinate, each $100 \mu$ mole; water to $1.0 \mathrm{ml}$. The mixtures were incubated in $1.5 \mathrm{~cm}$. diameter tubes for $2 \mathrm{hr}$. at $30^{\circ}$ before stopping the reaction by adding $1 \mathrm{ml}$. of $10 \%(\mathrm{w} / \mathrm{v})$ trichloroacetic acid. The amount of ALA formed was estimated colorimetrically after condensation with aminoacetone by the method of Mauzerall \& Granick (1956).

$\delta$-Aminolaevulic acid dehydrase activity was estimated as previously described (Lascelles, 1959).

One unit of ALA synthetase or ALA dehydrase is defined as that amount which catalyses the formation of $1 \mu \mathrm{m}$-mole of ALA or porphobilinogen (PBG) respectively under the standard conditions of assay.

Expression of results. Enzymic activity has been expressed as units of enzyme/ml. 
culture. The protein content of the culture, from which each extract was derived, was known to be $50 \%$ of the dry wt. of organism, and the amount of enzyme in units/ml. culture was derived from the specific activity of the extract (units of enzyme/mg. of extract protein). Results are plotted as units of enzyme or $\mu$ m-mole of bacteriochlorophyll $/ \mathrm{ml}$. culture against the dry wt. organism, so that the slopes represent the differential rate of synthesis (the ratio of the rate of enzyme synthesis to the rate of increase in total mass of organism). The theoretical basis of this measurement was discussed by Monod, Pappenheimer \& Cohen-Bazire (1952).

Chemicals. Stock solutions of haemin (Roche Products Ltd., Welwyn Garden City, Herts.) and protoporphyrin (L. Light and Co., Colnbrook, Bucks.) were at a concentration of $1 \mathrm{~mm}$ in $50 \%(\mathrm{w} / \mathrm{v})$ ethanol containing $0.05 \mathrm{M}-\mathrm{NaHCO}_{3}$. The potassium salt of magnesium protoporphyrin was prepared from protoporphyrin methyl ester by the method of Granick (1948). Stock solutions (0.4 mM) were prepared as above. Sources of other compounds used were described previously (Lascelles, 1959).

\section{RESULTS}

The effect of incubation conditions on rate of growth of Rhodopseudomonas spheroides and bacteriochlorophyll synthesis

The rate of growth under the three types of standard incubation (anaerobically in the light and aerobically in the dark with high and low aeration) were similar, the mean generation time being $2 \cdot 5-3 \mathrm{hr}$. (Fig. $2 a-c$ ). When growth ceased due to exhaustion of the carbon source the final yield of organisms in anaerobic +light cultures was almost twice that in aerobic cultures, as observed by Cohen-Bazire et al. (1957).

Synthesis of bacteriochlorophyll occurred anaerobically in the light, but in the dark the pigment was formed only under low aeration and reached less than onethird the concentration attained anaerobically in the light (Fig. 2). Increasing the light intensity with anaerobic cultures increased the growth rate but depressed the synthesis of bacteriochlorophyll (Fig. $2 a$ ), as previously shown by Cohen-Bazire et al. (1957).

\section{Effect of incubation conditions on the differential rate of synthesis of $\delta$-amino- laevulic acid synthetase and dehydrase}

The rates of synthesis of both ALA synthetase and ALA dehydrase were considerably influenced by the conditions of incubation. In cultures incubated anaerobically in the light under the standard conditions synthesis of both enzymes occurred at a constant rate, the amount of enzyme activity increasing linearly with the total mass of organisms between the limits $\mathbf{0} \cdot \mathbf{3}-\mathbf{1} \cdot \mathbf{0} \mathrm{mg}$. dry wt./ml. (Fig. $3 a$ ). Under these conditions the differential rate of synthesis of ALA synthetase varied in different experiments from 60 to 85 units/mg. dry wt. organism while that for ALA dehydrase was between 50 and 70 .

In cultures growing in the dark the rate of synthesis of both enzymes varied according to the degree of aeration. Under high aeration, where no bacteriochlorophyll was formed, the rates were decreased to about one-third of that found anaerobically in the light (Fig. $3 b$ ). Under low aeration, where bacteriochlorophyll 


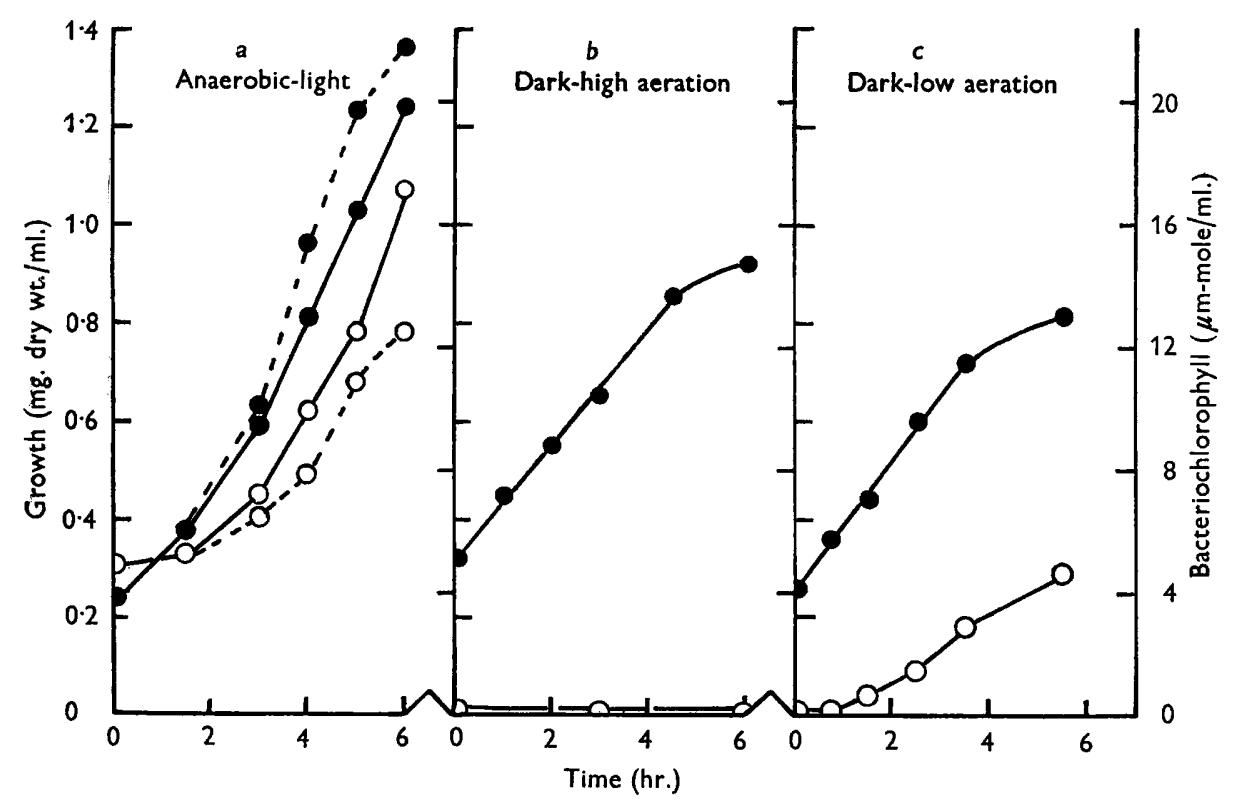

Fig. 2. Effect of incubation conditions on the rate of growth of Rhodopseudomonas spheroides (- - ) and bacteriochlorophyll synthesis (-O-). In (a) organisms harvested after anaerobic growth in light were resuspended in fresh medium and incubated anaerobically in light under standard conditions $(-)$ or in front of a $275 \mathrm{~W}$. photoflood lamp (- - -). In (b) and (c) organisms harvested after aerobic growth in dark were resuspended in fresh medium and incubated in dark under high aeration $(b)$ or low aeration $(c)$ as described in Methods.

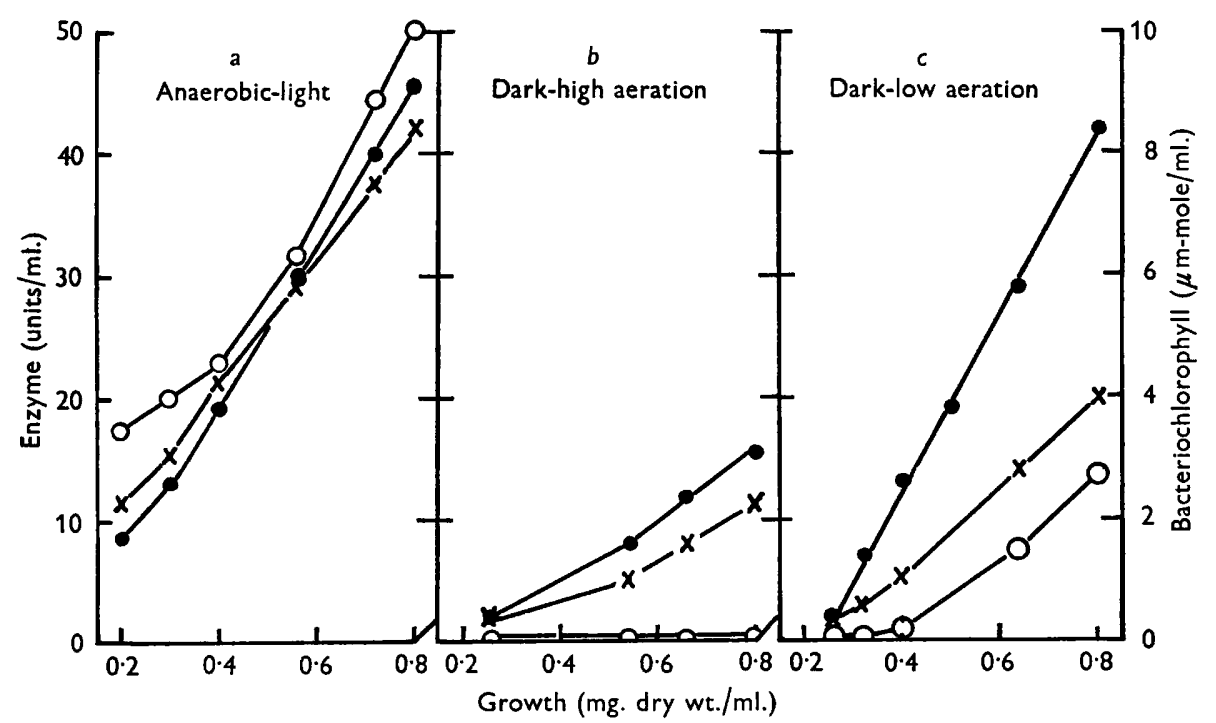

Fig. 3. Effect of incubation conditions on the synthesis of ALA synthetase (- - -), ALA dehydrase $(-\times-)$ and bacteriochlorophyll $(-\mathrm{O}-)$. In $(a)$ cultures were harvested after anaerobic growth in light, resuspended in fresh medium and incubated anaerobically in light under standard conditions. In $(b)$ and $(c)$ cultures were harvested after aerobic growth in dark, resuspended in fresh medium and incubated in dark under high aeration $(b)$ or low aeration $(c)$ as described in Methods. 
was synthesized, the rate of formation of ALA synthetase was the same as in anaerobic + light cultures, while that of ALA dehydrase was about $70 \%$ of that found anaerobically (Fig. $3 c$ ). Unlike enzyme synthesis under these conditions, the rate of bacteriochlorophyll formation did not reach a steady state. Synthesis of the pigment was not detected until the culture density reached about $0 \cdot 4 \mathrm{mg} / \mathrm{ml}$. and thereafter it was formed at an increasing rate (Fig. $3 c$ ).

The assay for ALA synthetase depended on the presence in the organisms of succinic thiokinase. The activity of this enzyme in extracts of organisms grown under all conditions described above was constant. When assayed as described previously (Lascelles, 1959) the specific activity was about $2 \cdot 1 \mu$ mole succinhydroxamate formed $/ \mathrm{hr} . / \mathrm{mg}$. protein, whatever the growth conditions.

Effect of light intensity. The rate of formation of ALA synthetase by cultures incubated anaerobically in the light was influenced by the light intensity in the

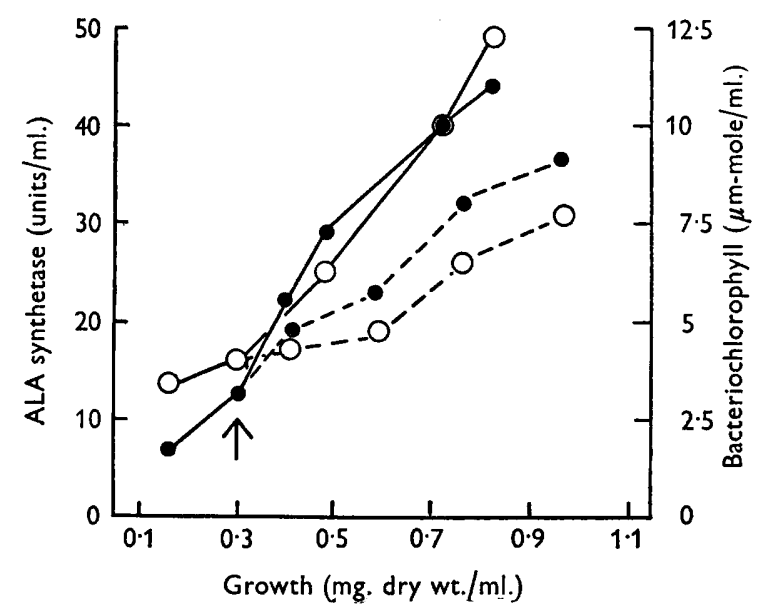

Fig. 4. Effect of light intensity on the synthesis of ALA synthetase (- - ) and bacteriochlorophyll $(-\mathrm{O}-)$. Organisms harvested after anaerobic growth in light were resuspended in fresh medium and incubated for $2.25 \mathrm{hr}$. anaerobically in light under standard conditions. At the point indicated by the arrow the culture was divided and one half incubated in front of a $275 \mathrm{~W}$. photoflood lamp (broken lines); the other half was continuously incubated under the standard conditions (100 W. lamp).

same way as was bacteriochlorophyll synthesis. When the illumination was increased by changing the light source from the standard one (a $100 \mathrm{~W}$. lamp) to a $275 \mathrm{~W}$. photoflood lamp the rate of formation of ALA synthetase was decreased to about one-half of that in the control culture incubated continuously under standard conditions (Fig. 4). The rate of synthesis of ALA dehydrase was decreased to a similar extent.

Effect of oxygen. Cohen-Bazire et al. (1957) found that synthesis of bacteriochlorophyll by cultures of Rhodopseudomonas spheroides growing in the light ceased abruptly when the gas phase of $\mathrm{N}_{2}+\mathrm{CO}_{2}$ was changed to one of air $+\mathrm{CO}_{2}$. Similar experiments under the present conditions showed that formation of both ALA synthetase and dehydrase was repressed by replacement of $N_{2}$ by air in the same way as bacteriochlorophyll synthesis (Fig. 5a,b); growth continued at the same 
rate when the gas phase was changed. Synthesis of both enzymes and of bacteriochlorophyll was resumed without a detectable lag when the gas phase was changed back to $5 \%(\mathrm{v} / \mathrm{v}) \mathrm{CO}_{2}$ in $\mathrm{N}_{2}$ (Fig. $\left.5 a, b\right)$. Indeed, the rates of synthesis of ALA synthetase and bacteriochlorophyll were increased after the period of aerobic incubation, so that the values quickly reached those found in control cultures incubated continuously in $\mathrm{N}_{2}+\mathrm{CO}_{2}$ (Fig. $5 a, b$ ).
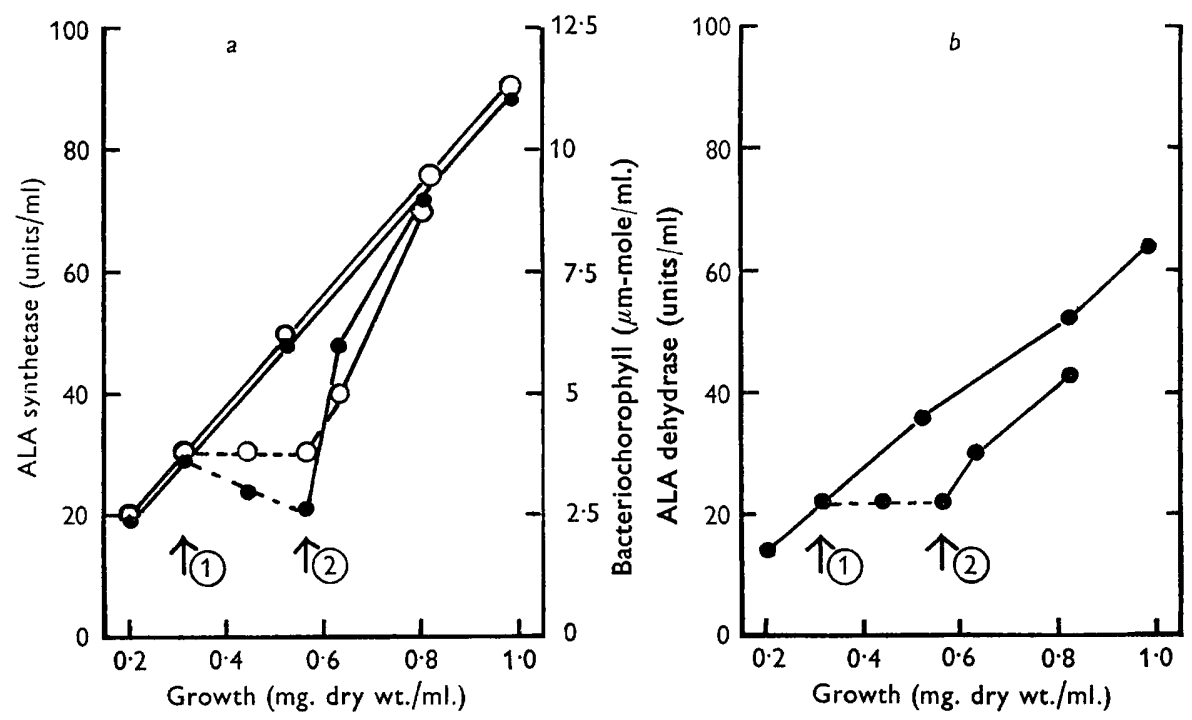

Fig. 5. Effect of oxygen on (a) the synthesis of ALA synthetase (-0 - ) and bacteriochlorophyll (-O-) and (b) on ALA dehydrase (- - ). Organisms, harvested after anaerobic growth in light, were resuspended in fresh medium and incubated for $2 \mathrm{hr}$. in light under $5 \%(\mathrm{v} / \mathrm{v}) \mathrm{CO}_{2}$ in $\mathrm{N}_{2}$. At the point indicated by the arrow (1) the culture was divided into two parts. One part was aerated with $5 \%(\mathrm{v} / \mathrm{v}) \mathrm{CO}_{2}$ in air for a further $1.75 \mathrm{hr}$. (broken lines) and at the point shown by arrow (2) the gas phase was changed back to $\mathrm{N}_{2}+\mathrm{CO}_{2}$. The other part of the culture (full lines) was kept continuously under $\mathrm{N}_{2}+\mathrm{CO}_{2}$. All cultures were incubated with continuous illumination.

\section{The repressing action of $\delta$-aminolaevulic acid and protoporphyrin derivatives}

Formation of ALA synthetase and ALA dehydrase by cultures growing anaerobically in the light was inhibited by addition of ALA at concentrations $(0 \cdot 1-0.5 \mathrm{~mm})$ which affected neither growth nor bacteriochlorophyll synthesis (Fig. 6, Table 1). Addition of ALA resulted initially in an actual decrease of ALA synthetase in the culture (Fig. 6); this was consistently observed. One possibility was that the organisms were forming from ALA a substance which inhibited ALA synthetase when assayed in the cell-free extracts. However, the ALA synthetase activity of extracts from organisms grown without ALA was not inhibited by addition of extracts prepared from cultures grown with ALA.

The inhibition of enzyme formation may not have been due to ALA itself, but to some metabolic product, possibly an intermediate in the synthesis of haem compounds or bacteriochlorophyll. Suspensions of Rhodopseudomonas spheroides, incubated anaerobically in the light with iron salts, convert ALA to protoporphyrin 
and iron protoporphyrin (Lascelles, $1956 a, b$ ) and the effect of these compounds on enzyme synthesis was therefore examined (Table 1). Low concentrations of iron protoporphyrin (added as haemin) inhibited the synthesis of both ALA synthetase and dehydrase but similar concentrations of protoporphyrin were ineffective. Also, magnesium protoporphyrin, a possible intermediate between ALA and bacteriochlorophyll, was inactive at concentrations up to $0.005 \mathrm{~mm}$.; higher concentrations were not tested because of the insolubility of this compound.
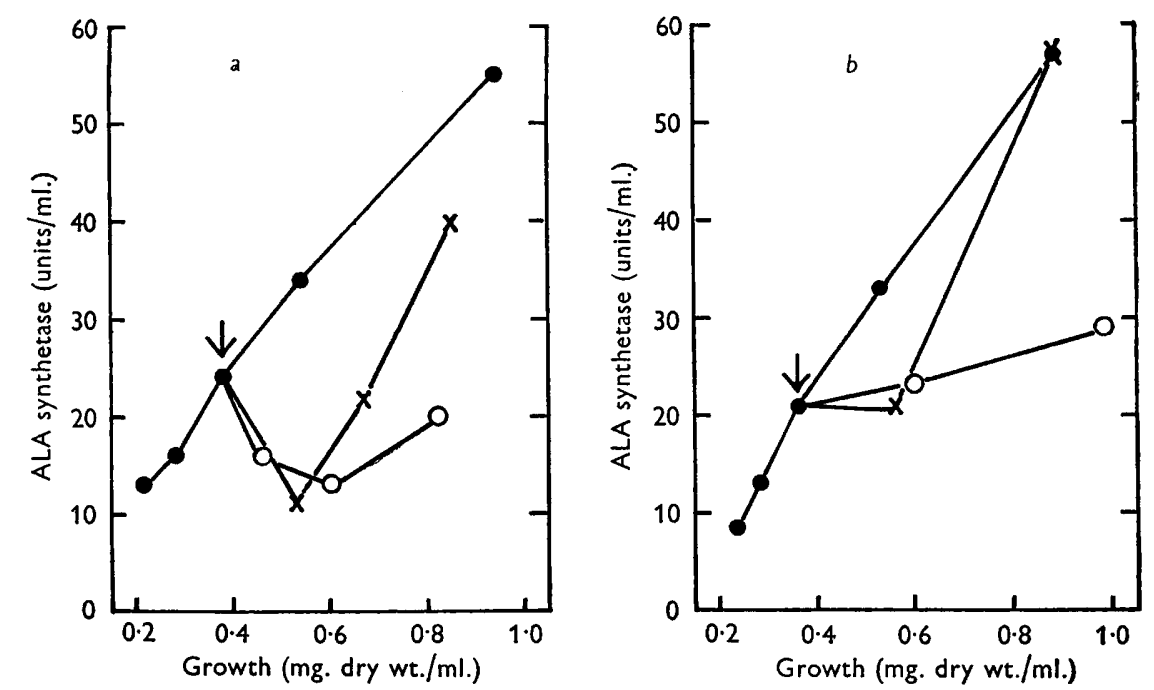

Fig. 6. Effect of ALA ( $a$ ) and haemin $(b)$ on the synthesis of ALA synthetase. Organisms, grown anaerobically in light, were harvested and suspended in fresh medium. In both experiments the cultures were incubated anaerobically in light for $2 \mathrm{hr}$. before dividing into equal portions and adding ALA or haemin (shown by the arrow). In (a) ALA was added to a final concentration of $0.1 \mathrm{~mm}(-x-)$ and $0.5 \mathrm{~mm}(-O-)$; no addition was made to the control culture (- - ). In $(b)$, haemin was added to give a final concentration of $0.003 \mathrm{~mm}$ $(-\times-)$ and $0.01 \mathrm{~mm}(-\mathrm{O}-)$; no addition was made to the control (-๑-).

Unlike the effect of ALA, addition of haemin to cultures did not result in an apparent decrease in the amount of ALA synthetase (Fig. $6 b$ ). The action of the two compounds was similar in that enzyme synthesis was gradually restored to the normal rate as growth proceeded after their addition. They may have been diluted out or converted to products which did not affect formation of ALA synthetase.

\section{Effect of biotin}

Rhodopseudomonas spheroides requires biotin for growth (Hutner, 1950) and it was observed previously that suspensions of biotin-deficient organisms did not synthesize porphyrins from glycine and $\alpha$-oxoglutarate though their ability to form them from ALA was unimpaired (Lascelles, 1956 a). This suggested that biotin may be required either for the formation or for the normal functioning of ALA synthetase. The observation that the activity of ALA synthetase was decreased in extracts of biotin-deficient organisms supports this (personal communication from Professor A. Neuberger and Mr G. Tait). 
The rate of formation of ALA synthetase by cultures growing anaerobically in the light was apparently influenced by the concentration of biotin in the medium. In these experiments organisms were harvested after anaerobic growth in the light in the standard medium modified by addition of biotin to $0 \cdot 2 \mu \mathrm{g} . / 1$., this being one-

Table 1. Effect of $\delta$-aminolaevulic acid and tetrapyrroles on synthesis of enzymes by cultures of Rhodopseudomonas spheroides growing anaerobically in the light

Organisms harvested after anaerobic growth in light were resuspended in fresh medium to a density equiv. $0 \cdot 28 \mathrm{mg}$. dry wt. $/ \mathrm{ml}$. Medical flat bottles $(2 \mathrm{oz}$.) were filled to the neck with $60 \mathrm{ml}$. portions of the suspension, additions made as shown and the bottles sealed with a rubber bung. The cultures were incubated for $4 \mathrm{hr}$. at $34^{\circ}$ in front of a bank of $60 \mathrm{~W}$. tungsten lamps. They were then prepared as usual for assay of enzyme activity.

Initial activities of the cultures before incubation were: ALA synthetase, 11 units/ml.; ALA dehydrase, 17 units $/ \mathrm{ml}$; initial bacteriochlorophyll $=4 \mu \mathrm{m}-\mathrm{mole} / \mathrm{ml}$.

Increase in

\begin{tabular}{|c|c|c|c|c|c|}
\hline \multirow{2}{*}{$\begin{array}{l}\text { Suspension } \\
\text { density } \\
\text { as dry wt. } \\
\text { (mg./ml.) }\end{array}$} & \multirow{2}{*}{$\begin{array}{c}\text { Bacterio- } \\
\text { chlorophyll } \\
(\mu \mathrm{m}-\mathrm{mole} / \mathrm{ml} .)\end{array}$} & \multicolumn{2}{|c|}{$\begin{array}{c}\text { Enzymes } \\
\text { (units/ml.) }\end{array}$} & \multicolumn{2}{|c|}{$\begin{array}{l}\text { rate of enzyme } \\
\text { synthesis }\end{array}$} \\
\hline & & $\begin{array}{l}\text { Synthe- } \\
\text { tase }\end{array}$ & $\begin{array}{c}\text { Dehy- } \\
\text { drase }\end{array}$ & $\begin{array}{l}\text { Synthe- } \\
\text { tase }\end{array}$ & $\begin{array}{l}\text { Dehy- } \\
\text { drase }\end{array}$ \\
\hline 0.40 & $7 \cdot 1$ & 34 & 25 & 85 & 62.5 \\
\hline 0.38 & $6 \cdot 8$ & 8 & 13 & 21 & 34 \\
\hline 0.40 & $6 \cdot 7$ & 11 & 14 & 28 & 35 \\
\hline $0 \cdot 40$ & $7 \cdot 0$ & 33 & 24 & 83 & 60 \\
\hline 0.44 & $7 \cdot 8$ & 35 & 27 & 80 & 61 \\
\hline
\end{tabular}

fiftieth the usual concentration. On transfer to fresh medium the organisms formed ALA synthetase at a differential rate which depended on the biotin concentration. In the control culture containing optimal biotin $(10 \mu \mathrm{g} . / 1$.$) the differential rate was$ 83 , but in cultures containing one-tenth and one-fiftieth this concentration the differential rates were decreased to 56 and 34, respectively (Fig. 7a). Synthesis of

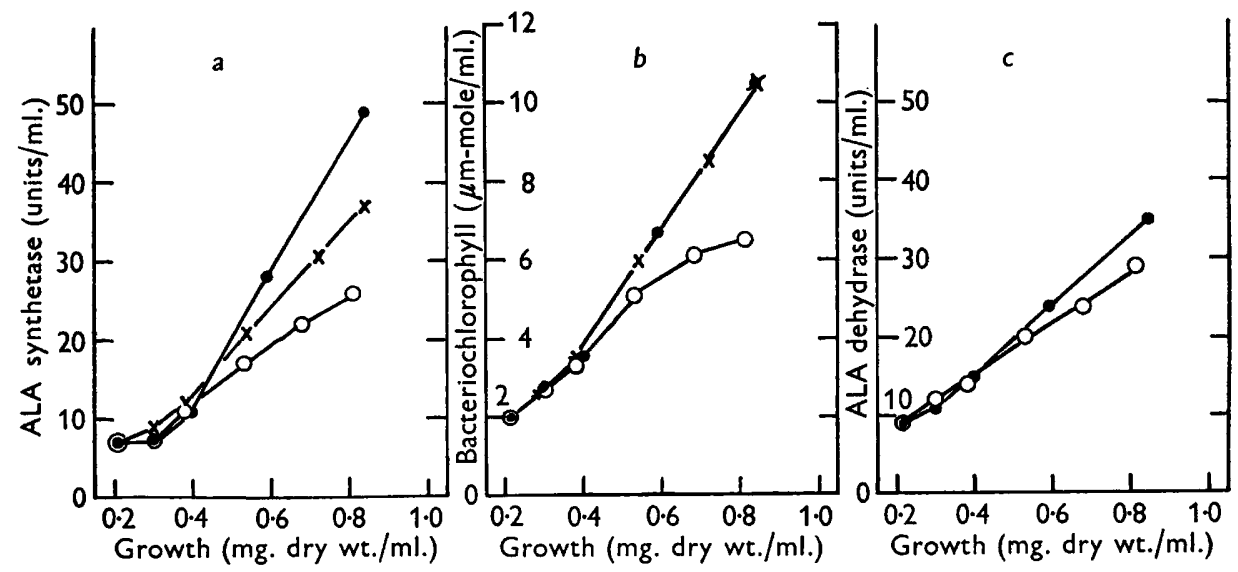

Fig. 7. Effect of biotin concentration on the synthesis of ALA synthetase (a), bacteriochlorophyll $(b)$ and ALA dehydrase $(c)$. Organisms were harvested after anaerobic growth in light in the standard medium except that the biotin concentration was decreased to $0.2 \mu \mathrm{g}$. $/ 1$.; they were resuspended in biotin-free medium and portions incubated anaerobically in light with addition of biotin as follows $(\mu \mathrm{g} . / 1):. 0 \cdot 2(-\mathrm{O}-) ; 1(-\times-)$ and 10 $(-0-)$. Samples were removed and prepared for assay as usual. 
bacteriochlorophyll was also decreased by biotin deficiency though to a smaller extent than was ALA synthetase (Fig. $7 b$ ). In contrast, the differential rate of synthesis of ALA dehydrase was not affected (Fig. 7c). The mean generation time of the cultures containing 10,1 and $0 \cdot 2 \mu \mathrm{g}$. biotin/l. were, respectively, $2 \cdot 8,3 \cdot 5$ and 4.4 $\mathrm{hr}$. Addition of biotin to extracts of deficient organisms did not increase their ALA synthetase activity.

\section{DISCUSSION}

It is clearly an advantage for Rhodopseudomonas spheroides and related organisms to be able to regulate the amount of bacteriochlorophyll synthesized to conform to the requirements imposed by the environment. Bacteriochlorophyll synthesis results in the utilization of glycine and succinyl CoA, which are intermediates in other essential metabolic reactions; a control mechanism which operates at the first stage in the synthesis, involving condensation of these compounds (i.e. ALA synthetase), might therefore be important to the organism. Such a mechanism would have to be delicately balanced since the bacteria must be able to synthesize some ALA under all conditions of growth in order to make haematin compounds, such as cytochromes, which are formed anaerobically in the light and aerobically in the dark.

The amount of ALA synthetase might be important in regulating the amount of glycine and succinyl $\mathrm{CoA}$ diverted towards tetrapyrrole synthesis; the present work has shown that synthesis of this enzyme is influenced by the conditions of growth in the same way as that of bacteriochlorophyll. Under highly aerobic conditions the differential rate of synthesis is about one-third of that in cultures growing anaerobically in the light. Also, synthesis of the enzyme is repressed by oxygen in cultures growing under continuous illumination. The light intensity, which influences bacteriochlorophyll formation under anaerobic conditions, also affects the synthesis of ALA synthetase, the differential rate being decreased by increasing the light intensity. Formation of ALA dehydrase is affected by the various conditions in the same way as its ALA synthetase. This is in accord with observations on other metabolic pathways in which formation of a number of enzymes in a biosynthetic sequence is repressed simultaneously by the same agent (see, for instance, Ames \& Garry, 1959). The amounts of enzymes concerned in later stages of tetrapyrrole synthesis are probably also influenced by the environment. The enzyme systems in Rhodopseudomonas spheroides responsible for conversion of porphobilinogen to uroand coproporphyrinogens (see Fig. 1), which have been studied recently (Heath \& Hoare, 1959; Hoare \& Heath, 1959) are less active in extracts from aerobic organisms than in those from photosynthetically grown organisms (personal communication from Dr D. Hoare).

The present work has given no indication of the precise mechanism by which oxygen exerts its repressing effect on enzyme synthesis. The hypothesis of CohenBazire et al. (1957) that pigment synthesis is regulated by the concentration of a component in the electron transport chain seems, from the present data, to apply equally well to the synthesis of the enzymes. The repressing effect of oxygen on the formation of ALA synthetase and dehydrase cannot fully account for its action on bacteriochlorophyll synthesis. If this were so pigment formation would not cease abruptly on the introduction of oxygen but would proceed at a decreasing differential 
rate as growth continued and the enzymes in the culture were diluted out. Oxygen may possibly inhibit the action of one or more of the enzymes concerned in bacteriochlorophyll synthesis. Such an affect has been observed with chick red cells where conversion of glycine to porphyrins and haem is inhibited by high tensions of oxygen (Falk, Porra, Brown, Moss \& Larminie, 1959). Another possibility is that oxygen acts indirectly by causing the accumulation of a substance which inhibits the action of a key enzyme.

It is difficult to assess the physiological significance of the repressing effect shown with $\delta$-aminolaevulic acid (ALA). In the many examples of enzyme repression now known to operate in a variety of biosynthetic pathways the end product of the reaction sequence (e.g. an amino acid) prevents enzyme synthesis (see, for instance, Vogel, 1957). By analogy, ALA itself may not exert the repressing effect but may act by serving as a precursor of an active tetrapyrrole; it is possibly significant that haemin also is an active repressor of the formation of ALA synthetase and dehydrase. More definite information must wait until synthesis of the enzymes has been obtained in cell-free systems where there is no problem of impermeability to products of ALA metabolism and until more is known of the pathways leading from protoporphyrin to bacteriochlorophyll and to haem proteins.

The observed effects of biotin deficiency might be interpreted in two ways. Biotin, probably in some combined form, may be a cofactor of ALA synthetase or it may be needed for the synthesis of the enzyme. The fact that addition of biotin to deficient extracts had no effect is not necessarily significant since the extracts may have been unable to convert it to its coenzyme form. The nature of the biotin effect cannot be established until the enzyme has been purified and its mechanism of action established. Recent work has shown biotin to be a cofactor in several enzymes concerned in the metabolism of fatty acids; all the reactions involve transfer of $\mathrm{CO}_{2}$ (Lynen, Knappe, Lorch, Jütting \& Ringelmann, 1959). It may be significant that the action of ALA synthetase results in the liberation of $\mathrm{CO}_{2}$ from the carboxyl group of glycine (Kikuchi et al. 1959).

I wish to thank Professor D. D. Woods, F.R.S., for his interest and Mr R. W. Wakelin for the preparation of magnesium protoporphyrin. This work was supported by a grant from the Rockefeller Foundation to the Department. The author is a member of the External Scientific Staff, the Medical Research Council.

\section{REFERENCES}

Ames, B. N. \& Garry, B. (1959). Coordinate repression of the synthesis of four histidine biosynthetic enzymes by histidine. Proc. nat. Acad. Sci., Wash. 45, 1453.

Cohen-Bazire, G., Sistrom, W. R. \& Stanier, R. Y. (1957). Kinetic studies of pigment synthesis by non-sulfur purple bacteria. J. cell. comp. Physiol. 49, 25.

COOPER, R. (1956). The production of coproporphyrin precursors by a Rhodopseudomonas sp. Biochem. J. 63, 25 P.

Falk, J. E., Porra, R. J., Brown, A., Moss, F. \& Larminie, H. E. (1959). Effect of oxygen tension on haem and porphyrin biosynthesis. Nature, Lond. 184, 1217.

Grison, K. D. (1958). Biosynthesis of $\delta$-aminolaevulic acid by extracts of Rhodopseudomonas spheroides. Biochim. biophys. Acta, 28, 451.

Granick, S. (1948). Magnesium protoporphyrin as a precursor of chlorophyll in Chlorella. J. biol. Chem. 175, 333. 
Heath, H. \& Hoare, D. S. (1959). The biosynthesis of porphyrins from porphobilinogen by Rhodopseudomonas spheroides. Biochem. J. 72, 14.

Heyningen, W. E. van \& Gladstone, G. P. (1953). The neurotoxin of Shigella shigae. 3. The effect of iron on production of the toxin. Brit. J. exp. Path. 34, 221.

Hoare, D. S. \& Heath, H. (1959). The biosynthesis of porphyrins from porphobilinogen by Rhodopseudomonas spheroides. 2. The partial purification and some properties of porphobilinogen deaminase and uro-porphyrinogen decarboxylase. Biochem. J. 73, 679 .

Hu'tner, S. H. (1950). Anaerobic and aerobic growth of purple bacteria (Athiorhodaceae) in chemically defined media. J. gen. Microbiol. 4, 286.

Kinuchi, G., Kumar, A. \& Shemin, D. (1959). Mechanism of enzymatic synthesis of $\delta$-aminolevulinic acid. Fed. Proc. 18, 259.

Kikuchi, G., Kumar, A., Talmage, P. \& Shemin, D. (1958). The enzymatic synthesis of $\delta$-aminolevulinic acid. J. biol. Chem. 233, 1214.

LASCELlES, J. (1956a). The synthesis of porphyrins and bacteriochlorophyll by cell suspensions of Rhodopseudomonas spheroides. Biochem. J. 62, 78.

LASCELLES, J. $(1956 b)$. An assay of iron protoporphyrin based on the reduction of nitrate by a variant strain of Staphylococcus aureus: synthesis of iron protoporphyrin by suspensions of Rhodopseudomonas spheroides. J. gen. Microbiol. 15, 404.

Lascelles, J. (1959). Adaptation to form bacteriochlorophyll in Rhodopseudomonas spheroides: changes in activity of enzymes concerned in pyrrole synthesis. Biochem. $J$. $72,508$.

Lynen, F., Knappe, J., Lorch, E., Jütting, G. \& Ringelmann, E. (1959). Die biochemische Funktion des Biotins. Angero. Chem. 71, 481.

Mauzerall, D. \& Granick, S. (1956). The occurrence and determination of $\delta$-aminolaevulic acid and porphobilinogen in urine. J. biol. Chem. 219, 435.

Monod, J., Cohen-Bazire, G. \& Cohn, M. (1951). Sur la biosynthèse de la $\beta$-galactosidase (lactase) chez Escherichia coli. La specificité de l'induction. Biochim. biophys. Acta, 7, 585.

Monod, J., Pappenheimer, A. M. Jr. \& Cohen-Bazire, G. (1952). La cinétique de la biosynthèse de la $\beta$-galactosidase chez Escherichia coli considérée comme fonction de la croissance. Biochim. biophys. Acta, 9, 648.

NiEL, C. B. van (1944). The culture, general physiology, morphology and classification of the non-sulfur purple and brown bacteria. Bact. Rev. 8, 1 .

STICKLAND, L. H. (1951). The determination of small quantities of bacteria by means of the Biuret reaction. J. gen. Microbiol. 5, 698.

VOGEL, H. J. (1957). Repression and induction as control mechanism of enzyme biogenesis. The adaptive formation of acetylornithinase. In The Chemical Basis of Heredity, ed. by W. D. McElroy \& B. Glass, p. 276. Baltimore: Johns Hopkins Press. 